\title{
Guar, jantar, wheat straw, and rice hull composts as replacements for peat in muskmelon transplant production
}

\author{
Ghulam Mustafa ${ }^{1,2} \cdot$ Muhammad Arif Ali $^{1} \cdot$ Donald Smith $^{2} \cdot$ Timothy Schwinghamer ${ }^{2}$. \\ John R. Lamont ${ }^{2} \cdot$ Niaz Ahmed $^{1} \cdot$ Sajjad Hussain $^{3} \cdot$ Muhammad Arshad $^{4}$
}

Received: 4 July 2016/ Accepted: 15 October 2016/Published online: 26 October 2016

(c) The Author(s) 2016. This article is published with open access at Springerlink.com

\begin{abstract}
Purpose The demand for soilless media for vegetable transplant production is increasing. Economic constraints paired with concerns over the sustainability of peat mining have necessitated the replacement of peat with renewable and regionally abundant alternatives. The aim of this study was to develop from composts complete or partial substitutes for peat.

Methods Composted guar (Cyamopsis tetragonoloba), jantar (Sesbania aculeata), wheat (Triticum aestivum) straw, and rice (Oryza sativa) hulls adjusted to $10 \%$ airfilled porosity (AFP) were blended on a volumetric basis with peat moss at discrete levels $(0-50 \%)$. Total waterholding capacity, shrinkage, dry and wet bulk density, $\mathrm{pH}$, electrical conductivity, N, P, K, FE, B, and Zn concentrations of each compost, their blends, and a peat control were measured. The experimental media were used to grow muskmelon (Cucumis melo) plants in a greenhouse. Seed germination, shoot fresh weight, shoot height, leaf area,
\end{abstract}

Ghulam Mustafa

ghulamustafa7944@yahoo.com

1 Department of Soil Science, Faculty of Agricultural Sciences and Technology, Bahauddin Zakariya University, Multan 60800, Pakistan

2 Department of Plant Sciences, McGill University, Macdonald Campus, Raymond Building, Sainte-Anne-de-Bellevue, QC H9X 3V9, Canada

3 Department of Horticulture, Faculty of Agricultural Sciences and Technology, Bahauddin Zakariya University, Multan 60800, Pakistan

4 Institute of Environmental Sciences and Engineering, School of Civil and Environmental Engineering, National University of Sciences and Technology (NUST), Sector H-12, Islamabad 44000, Pakistan stem diameter, root length, and mineral nutrient concentrations of transplants were quantified. After transplanting in the field, the growth rates and yields were measured. Nonparametric regression was used to analyze the data.

Results The physiochemical parameters measured for most of the experimental media fell within the recommended range for growing media; however, $\mathrm{pH}$ for all media exceeded the recommended range. Media-containing guar and jantar composts generally contained more nutrients than media-containing rice hull or wheat straw composts. Fresh weight, height, and root length were generally greater for seedlings grown in media-containing rice hull compost than for those grown in media-containing other composts. Seedlings grown in media-containing guar or jantar composts generally had greater tissue nutrient concentrations.

Conclusions All blends produced acceptable seedlings; however, the largest seedlings, and greatest post-transplant growth rate and yield were produced in media containing $30-50 \%$ rice hull compost.

Keywords Compost $\cdot$ Peat moss $\cdot$ Potting media . Muskmelon · Cucumis melo

\section{Introduction}

Growing vegetable transplants in containers offers a number of advantages over direct seeding in the field. Transplant production allows for the control of root zone attributes, often through the selection of potting media composition. Potting media may contain a single ingredient or they may be a composite blend. Components with different characteristics may provide optimal physical and 
chemical properties for specific crops and cultural conditions (Bunt 1988).

Peat is one of the most commonly used potting media components and is defined by Zaccone et al. (2007) as:

"A blond to black organic material $(<25 \%$ by weight mineral matter) formed under waterlogged conditions from the partial decomposition of mosses and other bryophytes, sedges, grasses, shrubs, or trees. The structure of peat (from fibric to sapric), the relative proportions of $\mathrm{C}, \mathrm{H}$, and $\mathrm{O}$, and, consequently, main chemical and physical properties vary depending upon the botanical composition, and degree of decomposition".

Horticultural peat is graded and processed to have appropriate properties for uniform plant growth, such as low bulk density, high total porosity, and high nutrient exchange capacity (Blievernicht et al. 2012). It is, however, an effectively non-renewable resource (Sendi et al. 2013), and it can be expensive. Furthermore, there is an increasing suite of environmental concerns surrounding the harvest of peat, including the destruction of wetland ecosystems, the release of greenhouse gasses, and the incidence of smoldering fire phenomena (Zaccone et al. 2014). Due to the economic and environmental concerns surrounding the harvest of peat, suitable alternatives are needed (Roberston 1993), but currently lacking (Bullock et al. 2012).

A wide variety of organic wastes-as diverse as anaerobically digested dairy fiber (Lamont and Elliott 2016a, b), biochar (Steiner and Harttung 2014), pine tree substrate (Jackson et al. 2008), date palm wastes (Ghehsareh et al. 2012, 2013; Ghehsareh 2013), vermicomposts (Gupta et al. 2014; Haghighi et al. 2016), peanut waste (Torkashvand et al. 2015), and spent mushroom compost (Lopes et al. 2015) - have been evaluated as potting media components. The consistency of direct or partial peat replacements varies significantly (Chong 2005), and consequently, many produce unsatisfactory results (Bustamante et al. 2008; Jung and Yang 2014), due to the presence of phytotoxic compounds, pathogens, high salt contents, or unsuitable physical properties (Sharif et al. 2014). The lack of physical and chemical stability over time further limits the utility of many composts as peat replacements (Raviv 2005). It is difficult to obtain ideal characteristics in a single compost for all the crops (Do and Scherer 2013). Mixing peat with composts can minimize hazardous salinity levels of single material (Mahmoud et al. 2014). Some materials have been identified as acceptable peat alternatives, but they are not produced in sufficient quantity to impact the market, or they are too expensive, or they may be commonly contaminated with weed seeds or metal fragments (Beeson 1996; Hartz et al. 1996). Despite the challenges, composts can also have beneficial attributes, such as providing plant nutrients or suppressing disease or promoting the growth of beneficial microbes.

The composts used in this trial were made from leguminous guar (Cyamopsis tetragonoloba) and jantar (Sesbania aculeata), as well as non-leguminous wheat (Triticum aestivum) straw, and rice (Oryza sativa) hulls. Guar and jantar are herbaceous legumes commonly used in crop rotation or as green manures. Such crops have the potential to supply significant amounts of plant available $\mathrm{N}$. Currently, no research has been done to evaluate guar or jantar composts as peat alternatives. Rice hulls are an agricultural by-product, which are usually treated as waste. Globally, there are more than 100 million tons of rice hulls produced per year (Okafor and Okonkwo 2009).

The objective of this research was to evaluate guar, jantar, wheat straw, and rice hull composts as partial or complete substitutes of peat in growing media for muskmelon (Cucumis melo). To achieve this goal, the physiochemical properties of media with varying proportions of compost were analyzed. These blends were then used to grow muskmelon transplants, which were evaluated upon commercial maturity and after transplanting in the field.

\section{Materials and methods}

\section{Media preparation and analysis}

Composts of guar, jantar, wheat straw, and rice hulls were prepared through composting by Inckel et al.'s (2005) pit method. The composted materials were air-dried for 2 days and ground. The ground materials were divided into five size-based grades by sieve: $3.3-5,2-3.3,1-2,0.5-1$, and $<0.5 \mathrm{~mm}$. Air-filled porosity (AFP) is the volume of air retained in media after irrigation and full drainage (Sharif et al. 2014). Grades of each compost were mixed in various proportions to obtain an AFP of $10 \%$, as described in Mustafa et al. (2016). An AFP of $10 \%$ was identified as suitable for growing muskmelon transplants (Mustafa et al. 2016). The $10 \%$ AFP composts were blended with peat to produce the potting mixes used in subsequent trials and analysis. These mixes contained 10, 20, 30, 40, 50, and $100 \%$ composts, by volume, plus a $100 \%$ peat control. The $\%$ AFP, total water-holding capacity (TWHC), percent shrinkage, and wet and dry bulk densities of the potting media were determined according to Nkongolo and Caron (1999) and Sharman and Bodman (1993), as described in Mustafa et al. (2016).

To quantify $\mathrm{P}, \mathrm{K}, \mathrm{Zn}, \mathrm{Fe}$ content, $\mathrm{EC}$, and $\mathrm{pH}$, potting medium was mixed with distilled water in a 1:5 medium:water ratio and shaken in a horizontal shaker at $120 \mathrm{rpm}$ for $1 \mathrm{~h}$ and filtered to produce aqueous extracts (CEN 1999). The $\mathrm{pH}$ of extracts was measured using a 
Beckman Zero-Matic ${ }^{\circledR}$ pH meter (Beckman Coulter, Brea California, USA, Model: 511212), and electrical conductivity (EC) was determined using a CM-1 Mark Kent EC meter (Electric Instrument Ltd. England). The concentration of $\mathrm{K}$ in media was determined using a flame photometer (Jenway, PFP7, UK). The concentration of $\mathrm{P}$ in media was determined using a spectrophotometer and the molybdovanadate phosphoric acid method (Jones et al. 1991). The concentrations of $\mathrm{Fe}$ and $\mathrm{Zn}$ were determined using an atomic absorption spectrophotometer (Model Pye Unicam SP 2900, UK) (Jackson 1962). Total N was determined using sulfuric acid digestion and distillation with a Marco-Kjeldahl apparatus. The concentration of B was determined by dry-ashing (Grains and Mitchell 1979) and colorimetric measurement using the azomethine- $\mathrm{H}$ method as described by Bingham (1982). There were three replications for each compost and compost-peat blend.

\section{Transplant growth and field establishment}

Muskmelon (Melon 1, Syngenta) transplants were grown for 30 days after sowing in an unheated polyethylenecovered greenhouse $\left(25-30^{\circ} \mathrm{C}\right)$, at the farm of Bahaudin Zakariya University, Multan, Pakistan $\left(30^{\circ} 12^{\prime} \mathrm{N}, 71^{\circ} 29^{\prime} \mathrm{E}\right)$ in February, with natural daylight conditions, using the potting media blends described above. One tray was used for each replication and each treatment was replicated three times, following a completely random design. Plug trays (60 plugs per tray, plugs with $2.5 \mathrm{~cm}$ diameter, $5.5 \mathrm{~cm}$ depth) were filled with respective media and each plug was planted with one muskmelon seed. Trays were watered-in uniformly to maximum saturation and watered throughout the experiment, by hand, as needed.

Emergence percent was calculated by dividing the number of seedlings that emerged by the total number of seeds planted. For destructive measures, three transplants were harvested at random from each experimental unit plug tray, with the exception of tray edges. Transplant height was measured from the root collar to apical meristem. Leaves were collected, cleaned with tissue paper, and then measured using an LI-COR LI-3000 leaf area meter (LICOR, Lincoln, NE). Transplants were uprooted when the media were moist. Roots were washed and dried with tissue paper before weighing to determine the fresh weight of transplants. Stem diameter was measured below the cotyledon node with Vernier calipers.

For nutrient analysis, transplants were washed with distilled water and oven-dried at $70-80{ }^{\circ} \mathrm{C}$ for $48 \mathrm{~h}$. The dried transplants were ground and passed through a $1 \mathrm{~mm}$ sieve (Yoshida et al. 1978). Total nitrogen was determined using the method of Jackson (1962). One gram of plant material was digested in a mixture of $20 \mathrm{~mL}$ of concentrated $\mathrm{HNO}_{3}$ and $10 \mathrm{~mL}$ of $72 \% \mathrm{HClO}_{4}$. Samples were digested, cooled, and transferred to $100 \mathrm{~mL}$ volumetric flasks. Plant tissue P, Fe, Zn, and B concentrations were measured as described for the media samples above.

\section{Statistical analysis}

While parametric models were appropriate for guar, jantar, and wheat straw compost data, they did not fit the rice hull compost data well. To create a better model for the experiment, locally weighted scatterplot smoothing (LOESS) procedures were used instead (Cleveland and Devlin 1988). LOESS is a nonparametric procedure for hypothesis testing that is not based on any assumptions about the probability distributions of the variables being tested (Sheskin 2004). Analysis was conducted using SAS PROC SGPLOT with the LOESS statement (SAS Institute Inc., Cary, NC, USA).

\section{Results}

\section{Media analysis}

Total water-holding capacity (TWHC) of guar, jantar, and wheat straw composts increased with increasing percentage of composts (Fig. 1a). Conversely, TWHC decreased with increasing percentage of rice hull compost with $100 \%$ rice hull compost having the smallest TWHC (Fig. 1a). Blends that contained $10 \%$ of each compost had TWHC similar to the $100 \%$ peat control (Fig. 1a). The shrinkage increased with increasing proportions of compost in the experimental media (Fig. 1b). The addition of guar compost or jantar compost resulted in the greatest shrinkage, with guar $>$ jantar, where the proportions were $\geq 50 \%$ $(\alpha=0.05)$. The addition of wheat straw compost resulted in lower levels of shrinkage, and the addition of rice hull compost resulted in the lowest levels of shrinkage (Fig. 1b). Dry bulk density increased with increasing proportions of all composts. The observed values of wet bulk density from the $100 \%$ peat controls were, for all but one experimental unit, higher than the values of wet bulk density observed from the experimental mixtures. Wet bulk density decreased as the compost percentages increased from 10 to $50 \%$. The lowest levels of wet bulk density were observed for $50 \%$ guar and jantar composts. Samples that contained 10 or $100 \%$ of all composts had similar wet bulk densities (Fig. 1d).

The $\mathrm{pH}$ of 1:5 extract samples of guar and jantar composts increased with increasing compost proportions up to $50 \%$ compost; however, the $\mathrm{pH}$ of the $50 \%$ guar compost media was similar to that of the $100 \%$ guar compost, and the $\mathrm{pH}$ of the $10 \%$ jantar compost media was similar to that of the $100 \%$ jantar compost. The $\mathrm{pH}$ of media with wheat 


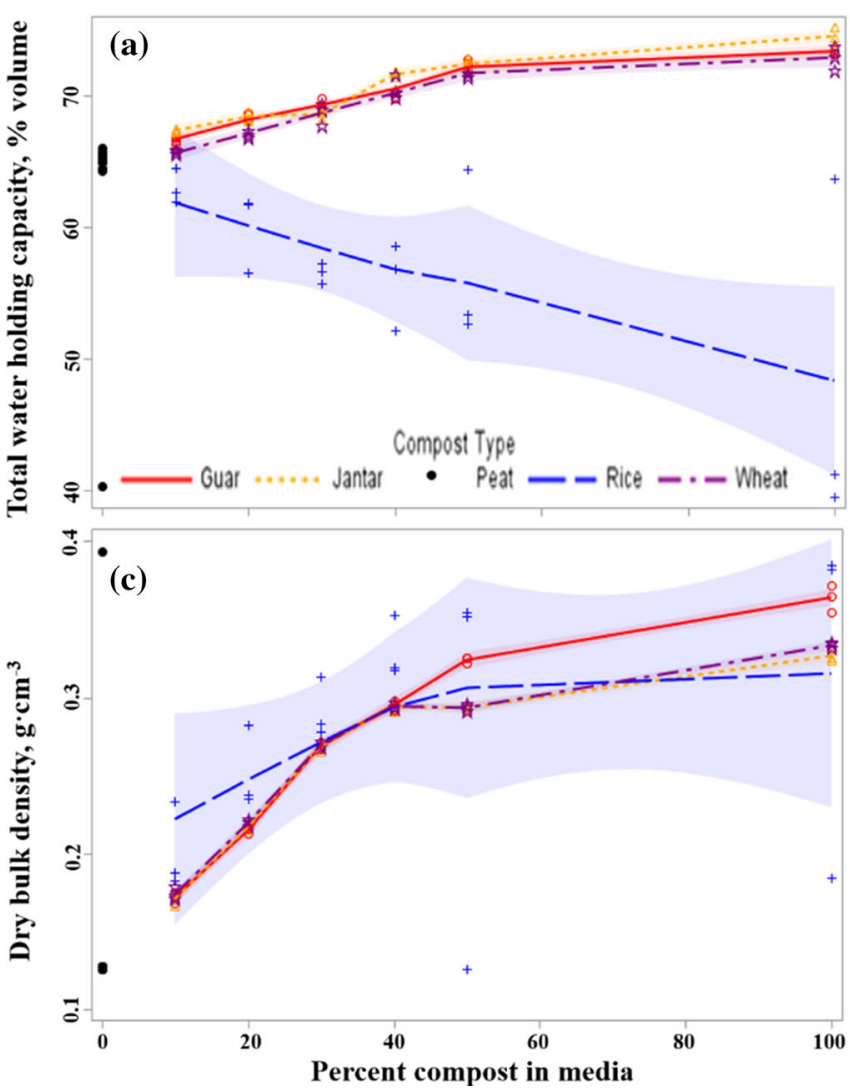

Fig. 1 Non-parametric regressions of total water-holding capacity (a), shrinkage (b), dry bulk density (c), and wet bulk density (d) of media with guar, jantar, wheat straw, and rice hull compost combined

straw compost increased with increasing proportions of compost. The $\mathrm{pH}$ of media-containing rice hull composts was not greatly affected by varying proportions of compost (Fig. 2a). The EC of media increased with the addition of guar and jantar composts and decreased with the addition of wheat straw and rice hull composts with all blends containing $10 \%$ composts having an EC similar to the $100 \%$ peat control (Fig. 2b).

Total $\mathrm{N}$ increased with the addition of both guar and jantar composts, to approximately twice as much total $\mathrm{N}$ in $100 \%$ guar and jantar composts as in the $100 \%$ peat compost (Fig. 2c). In contrast, total $\mathrm{N}$ decreased with increasing proportions of wheat straw and rice hull composts with $100 \%$ rice hull compost having a total $\mathrm{N}$ concentration close to 0 (Fig. 2c). This indicated the higher $\mathrm{N}$ content of peat, on average, compared to wheat straw and rice hulls. Concentrations of $\mathrm{P}$ and $\mathrm{K}$ increased with increasing proportions of guar, jantar, and wheat straw composts, and, while 50\% guar, jantar, and wheat straw compost blends had statistically similar amounts of $\mathrm{P}$, $100 \%$ guar had the greatest concentration of $\mathrm{P}$ and $\mathrm{K}$ overall. Concentrations of $\mathrm{P}$ and $\mathrm{K}$ were not greatly affected by varying proportions of rice hull compost, and

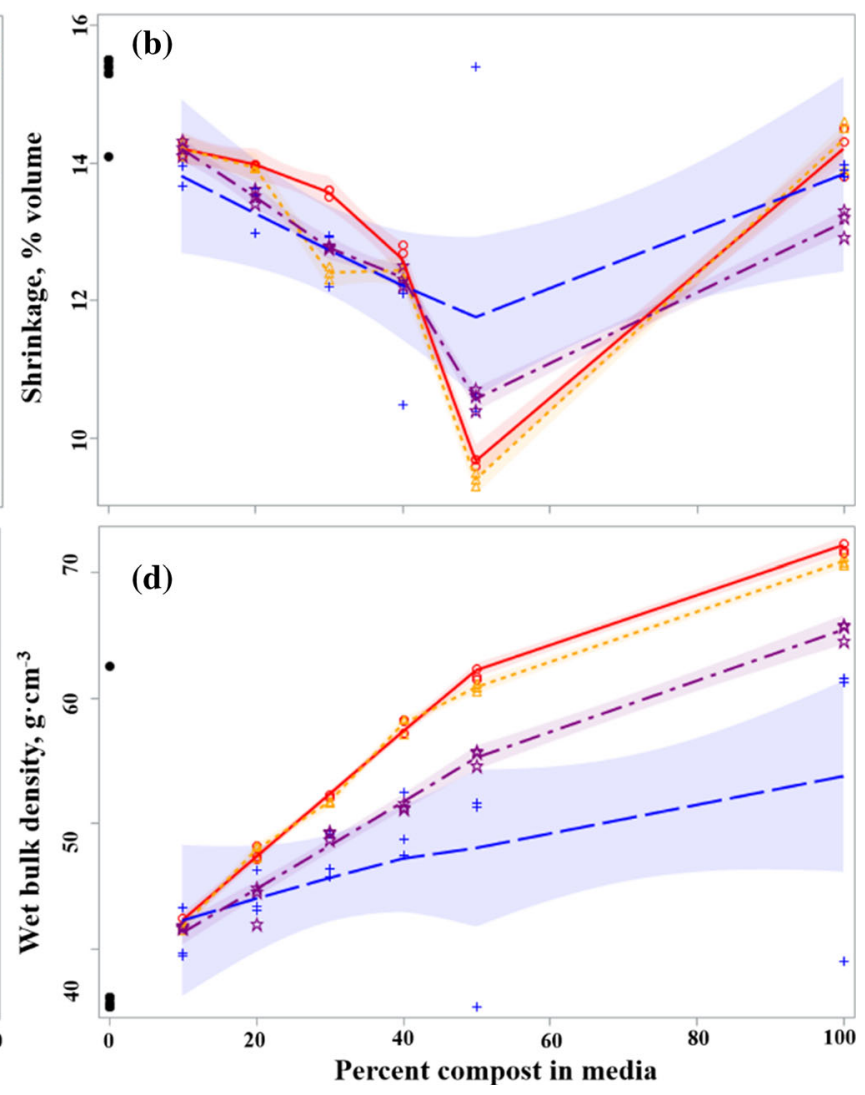

in varying proportions of peat. Shaded areas represent $95 \%$ confidence intervals. Symbols represent data points correlating to their, respectively, colored regression line

remained slightly lower than that of the $100 \%$ peat control (Fig. 2d, e). Concentrations of $\mathrm{Fe}$ and $\mathrm{B}$ remained similar to the $100 \%$ peat control across all proportions of guar and jantar composts and decreased with increasing proportions of wheat straw and rice hull composts (Fig. 2f, g). This indicated the relatively lower levels of $\mathrm{Fe}$ and $\mathrm{B}$ to be found in wheat straw and rice hulls as compared to peat. The pattern of Fe and B was similar for $\mathrm{Zn}$, except $\mathrm{Zn}$ only decreased with the addition of wheat straw compost up to $50 \%$, but had a similar $\mathrm{Zn}$ concentration in 100 and $10 \%$ wheat straw compost blends (Fig. 2h). Overall, samples of media-containing guar and jantar composts contained greater amounts of nutrients than the rice hull or wheat straw compost media.

\section{Transplant growth and field establishment}

The levels of germination modeled by nonparametric regression, for all of the experimental media, were within the range of approximately $87-93 \%$. The fresh weight of transplants grown in all media-containing guar, jantar, and wheat straw composts was significantly less than the $100 \%$ peat control. Fresh weight of transplants increased slightly 

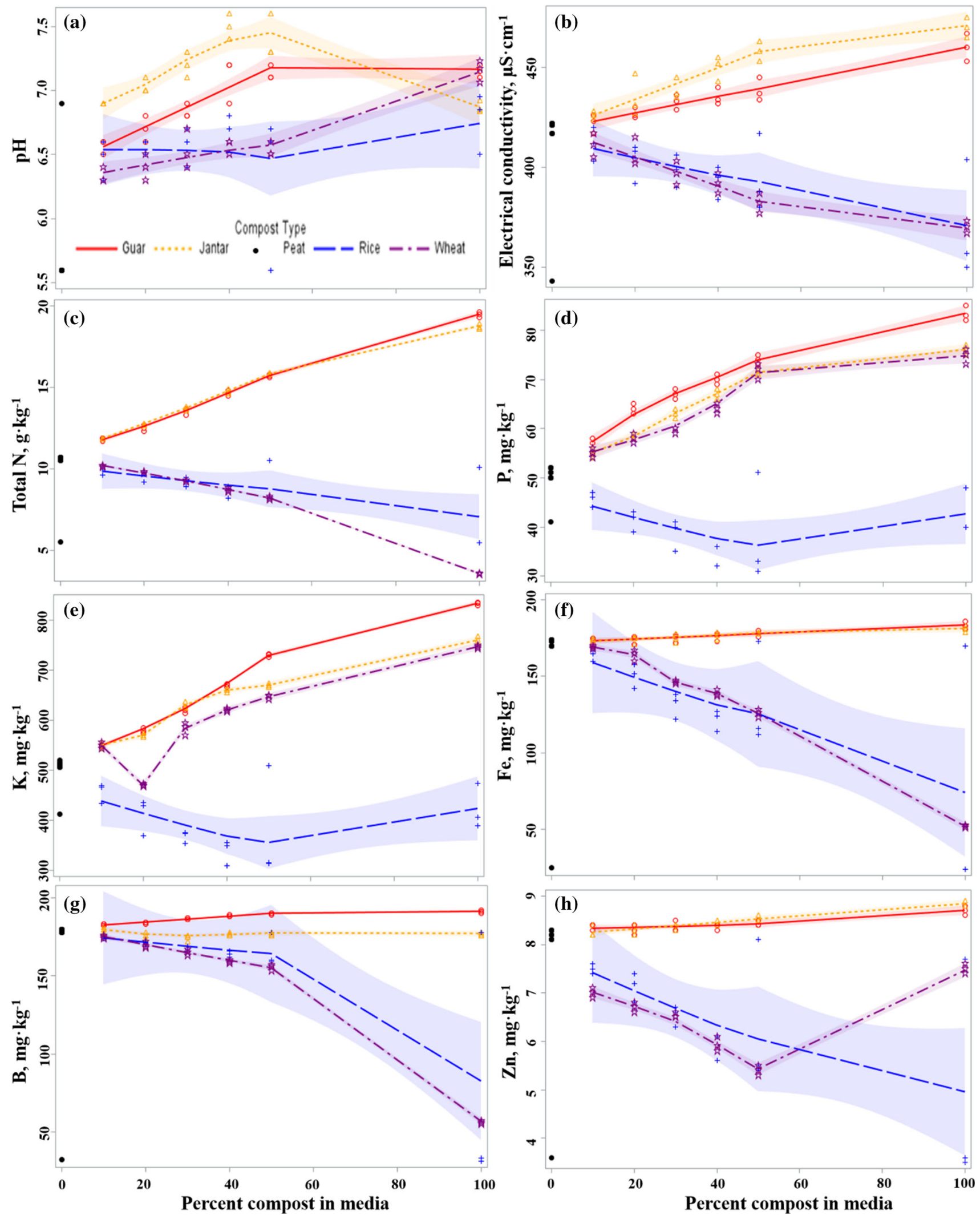

Fig. 2 Non-parametric regressions of the $\mathrm{pH}(\mathbf{a})$, electrical conductivity (b), total $\mathrm{N}$ concentration $(\mathbf{c})$, and $\mathrm{P}(\mathbf{d}), \mathrm{K}(\mathbf{e}), \mathrm{Fe}(\mathbf{f}), \mathrm{B}(\mathbf{g})$, and $\mathrm{Zn}$ (h) concentrations of media with guar, jantar, wheat straw, and

rice hull compost combined in varying proportions of peat. Shaded areas represent $95 \%$ confidence intervals. Symbols represent data points correlating to their, respectively, colored regression line 
with increasing proportions of rice hull compost up to $50 \%$ compost. While the $50 \%$ rice hull blend produced the greatest transplant fresh weight, it was not significantly different from the 20,30 , or $100 \%$ rice hull compost media (Fig. 3b). Varying proportions of jantar and wheat straw composts did not greatly affect transplant height, although blends of 50\% compost produced somewhat taller plants. Media-containing guar compost produced a similar trend in transplant height to the jantar and wheat straw composts, except there was a dramatic decrease in height for the $20 \%$
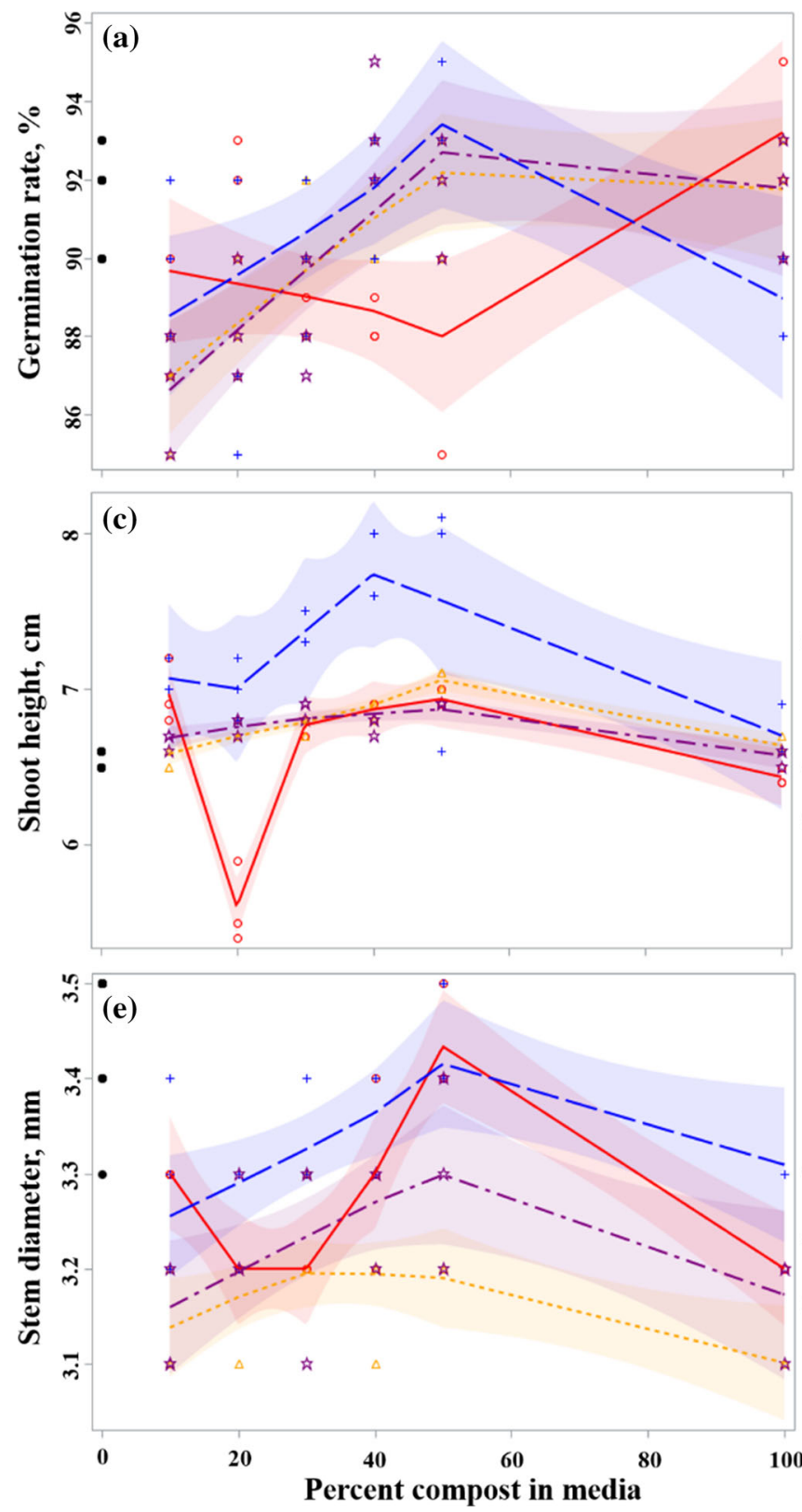

Fig. 3 Non-parametric regressions of the germination (a), fresh weight (b) shoot height (c), leaf area (d), stem diameter (e), and root length (f) of muskmelon transplants grown in media with guar, jantar, wheat straw, and rice hull compost combined in varying proportions guar blend. Plant height increased with the addition of rice hull compost up to $50 \%$ rice hull compost, which produced the tallest plants overall. The 10 and $100 \%$ rice hull compost media all produced plants of similar height (Fig. 3c). Leaf area varied little across compost types and proportions (Fig. 3d). Stem diameter varied little across compost proportions within a compost type, but mediacontaining rice hulls generally produced thicker stems than media-containing jantar or wheat straw compost (Fig. 3e). Root length was greater for plants grown in media-
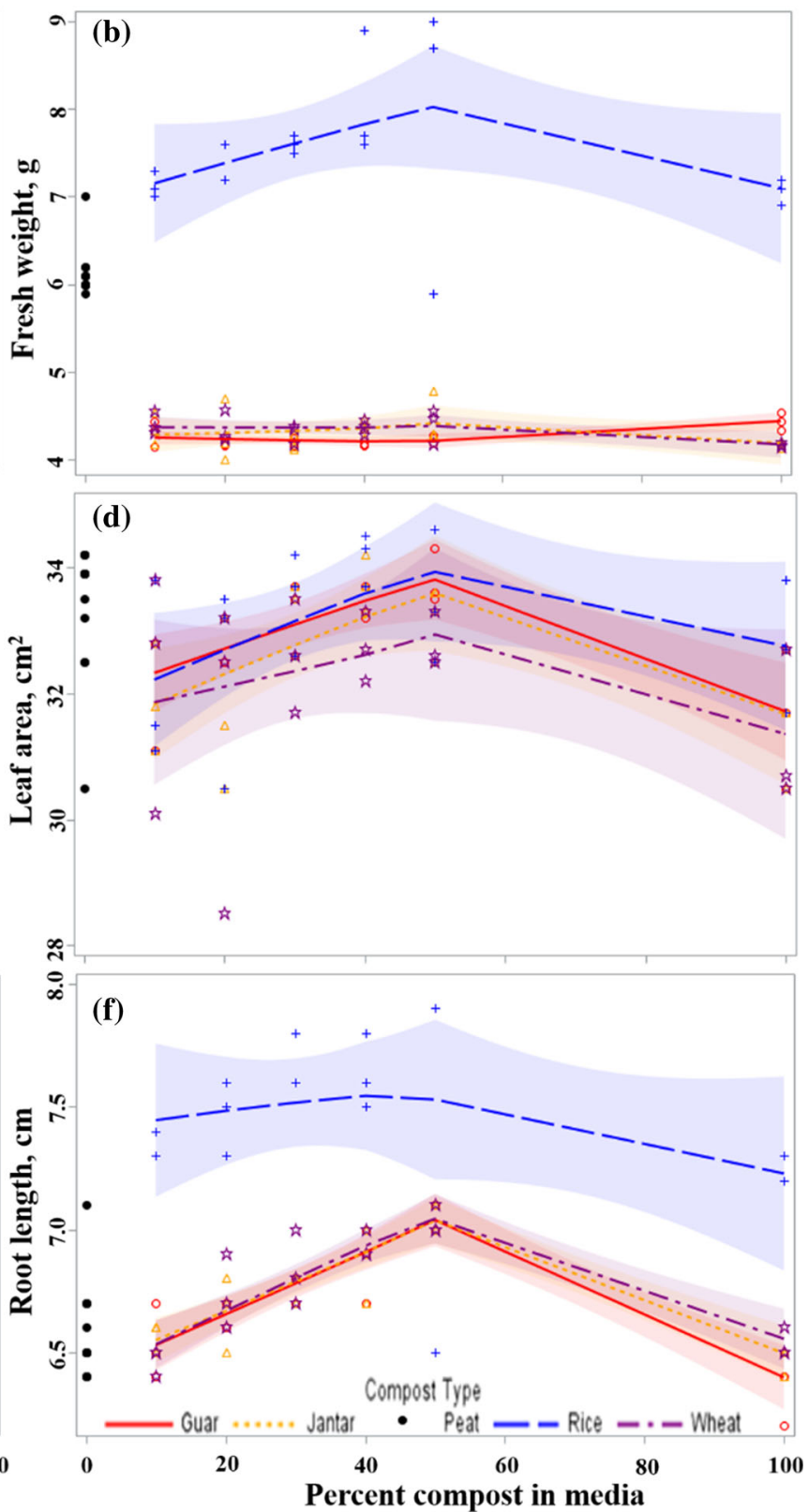

of peat. Shaded areas represent $95 \%$ confidence intervals. Symbols represent data points correlating to their, respectively, colored regression line 
containing rice hull compost than for the other composts but did not vary greatly with increasing proportions of rice hull composts (Fig. 3f). Overall, media-containing rice hull composts, especially at the $50 \%$ proportion, produced larger, more vigorous transplants than the other compost blends. The nonparametric model generated an intercept for leaf area and root length in rice hull compost that was very different from the other composts, indicating that small additions of rice hull compost can significantly affect transplant leaf area and root length.

Transplants grown in media-containing guar compost had the greatest $\mathrm{N}$ concentrations, followed by those grown in media-containing jantar compost, with tissue $\mathrm{N}$ concentration increasing with increased proportion of these composts. In contrast, transplants grown in the wheat straw and rice hull compost blends had significantly less $\mathrm{N}$ and decreased in concentration with the addition of these composts. Transplants grown in the blends containing wheat straw and rice hull compost up to $50 \%$ had similar N concentrations; however, transplants grown in $100 \%$ rice hull had greater $\mathrm{N}$ concentrations than those grown in $100 \%$ wheat straw compost (Fig. 4a). Transplant $P$ concentration increased with increasing proportions of all composts; however, $\mathrm{P}$ concentrations increased more with the addition of guar and jantar than with wheat straw and rice hull composts. Wheat straw compost additions increased $\mathrm{P}$ concentrations of tissues slightly more than rice hull compost (Fig. 4b). Transplant K concentrations increased with the addition of jantar, and especially guar composts. Transplant K concentrations increased only slightly with the addition of wheat straw and rice hull composts (Fig. 4c). Transplant micronutrient concentrations increased similarly with the addition of guar and jantar composts, although B concentration increased more with the addition of jantar. Conversely, transplant micronutrient concentrations decreased similarly with the addition of wheat straw compost and rice hull compost. Transplant Fe concentrations were, however, slightly greater in the $100 \%$ rice hull blend than in the $100 \%$ wheat straw blend (Fig. 4d-f). Overall, transplants grown in media-containing guar or jantar compost had greater quantities of all measured nutrients than those grown in the wheat straw and rice hull composts.

After transplantation, plants grown in the rice hull compost blends, especially those with $30-50 \%$ rice hull compost, had the greatest growth rate and yield. Overall, growth rate and yield for the other composts were not greatly affected by type or proportion (Fig. 5a, b).

\section{Discussion}

Overall, transplants grown in the 30-50\% rice hull compost blend were the largest and most vigorous, and had the best performance when transplanted in the field. The success of the rice hull compost blends was due to good physical and chemical properties, many of which were quite different for rice hull compost than the other composts. The good physical and chemical characteristics of rice hull compost blends enabled good transplant establishment and growth, leading to vigorous transplants and, in turn, well established, high yielding plants in the field.

While the ranges of TWHC and shrinkage in these composts corresponded with Kuisma et al. (2014) and Ghehsareh et al. (2013), all of the composts had relatively high dry bulk densities $(>0.3)$, and except for rice hull compost, high water-holding capacity and shrinkage. These characteristics are apt to lead to compaction and water logging (Raviv 2011). The low TWHC of rice hull compost likely allowed good drainage, avoiding the risk of waterlogging. Peat and rice hull compost likely have complimentary physical properties that, when blended in the correct ratio, providing ideal root zone properties. The similarity of wet bulk densities for 10 and $100 \%$ composts may be due to interactions between particles from peat and compost, or due to fluffing during mixing.

The $\mathrm{pH}$ of all media and blends was outside of the recommended range of 5.5-6.3 for 1:5 extracts of composts as potting media components (Sánchez-Monedero et al. 2004), although wheat straw and rice hull compost blends up to $50 \%$ were close to the recommended range. In soilless potting media, high $\mathrm{pH}$ values, such as those measured in guar and jantar compost blends, can greatly reduce the availability of $\mathrm{P}$ and many micronutrients, leading to nutrient deficiencies (Dole and Wilkins 1999). The EC of all composts and their blends fell below the recommended threshold of $<500 \mu \mathrm{S} \mathrm{cm}$ for composts in potting media (Ceglie et al. 2015). The decrease of EC with the addition of guar and jantar composts may be due to more moisture contained in these composts with higher TWHC. Guar and jantar compost had greater quantities of $\mathrm{N}, \mathrm{P}$, and $\mathrm{K}$ than the $100 \%$ peat control and blends of these composts contained significant concentrations of these macronutrients. Guar and jantar composts contained similar amounts of Fe, $\mathrm{B}$, and $\mathrm{Zn}$ to peat so their addition to peat did not greatly alter micronutrient concentrations. It is unsurprising that these leguminous crops contain significant amounts of nutrients, since they are used as green manures and able to engage in symbiotic relationships with rhizobia to fix atmospheric nitrogen into a bioavailable form. Wheat straw compost contributed amounts of $\mathrm{P}$ and $\mathrm{K}$ to blends similar to the leguminous composts. In contrast, rice hulls contained a smaller quantity of most measured nutrients than peat, and therefore, blends containing rice hulls contained fewer nutrients than the $100 \%$ peat control. More nutrients than those measured may have been released during plant growth as the method used to measure initial nutrient concentration only measures labile, water soluble nutrients. 

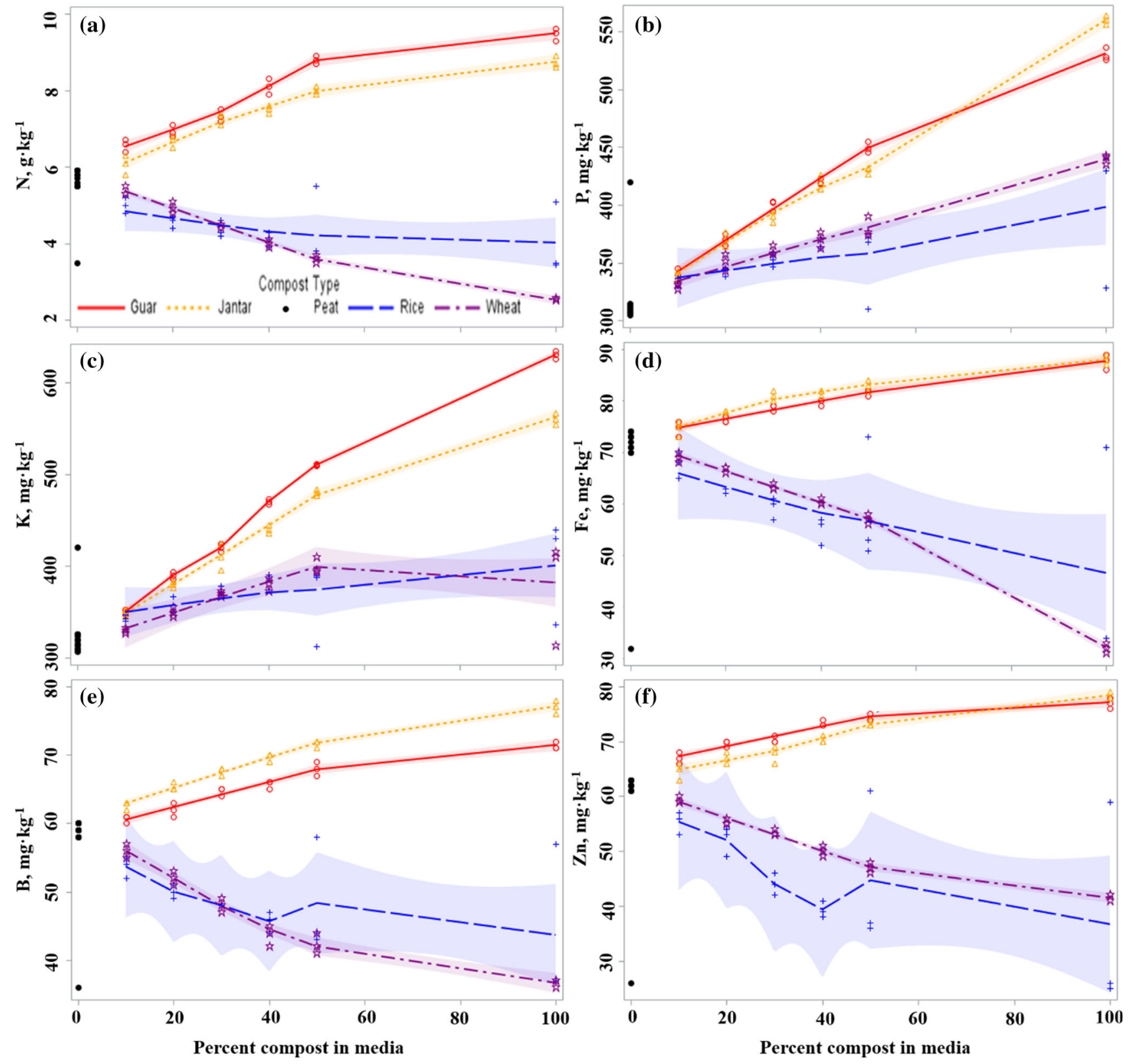

Fig. 4 Non-parametric regressions of the $\mathrm{N}(\mathbf{a}), \mathrm{P}(\mathbf{b}), \mathrm{K}(\mathbf{c}), \mathrm{Fe}(\mathbf{d})$, $\mathrm{B}$ (e), and $\mathrm{Zn}$ (f) tissue concentrations of muskmelon transplants grown in media with guar, jantar, wheat straw, and rice hull compost

More nutrients may have become available, as organic materials were decomposed by microbes or root exudates.

Despite the problems with nutrient availability that may have been expected with the high $\mathrm{pH}$ of the guar and jantar blends, the tissue nutrient analysis of transplants grown in these blends showed increasing concentrations of all nutrients with increasing proportions in the compost. Concentrations of all measured nutrients, except $\mathrm{P}$, of transplants grown in the wheat straw and rice hull compost blends did, however, decrease with increasing compost proportions. Because tissue $\mathrm{P}$ concentration increased with

combined in varying proportions of peat. Shaded areas represent $95 \%$ confidence intervals. Symbols represent data points correlating to their, respectively, colored regression line

increasing proportions of rice hull compost, it appears there is more plant available $\mathrm{P}$ in rice hull compost than the 1:5 extract samples suggested. Nutrients in composts can display varying degrees of extractability when composts are used in potting mixes due to complex interactions between media components (Evans et al. 2011). Interactions between media components could explain some of the discrepancies between nutrients measured in media blends and tissue nutrient concentration. There appears to be no clear relationship between transplant tissue nutrient concentration and transplant growth or field performance. With 


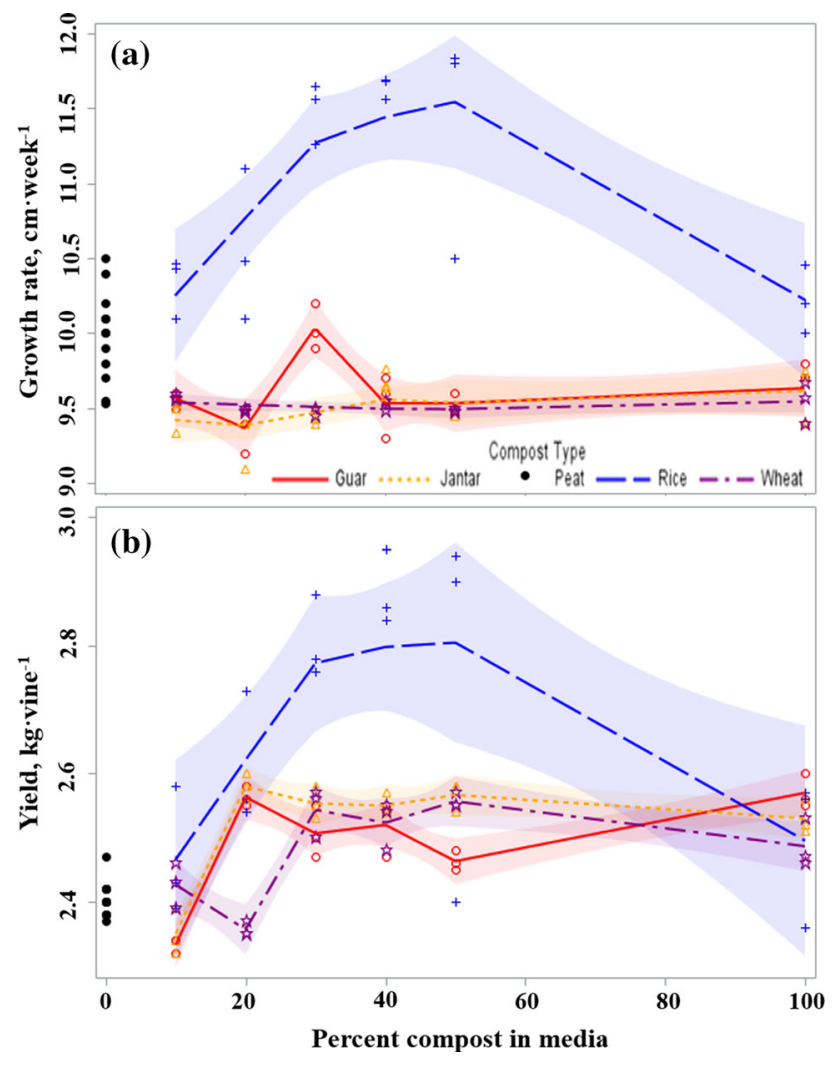

Fig. 5 Non-parametric regressions of growth rate (a) and yield (b) in the field of muskmelon transplant grown in media with guar, jantar, wheat straw, and rice hull compost combined in varying proportions of peat. Shaded areas represent $95 \%$ confidence intervals. Symbols represent data points correlating to their, respectively, colored regression line

this in mind, the good performance in rice hull compost blends is likely due to the differences in the physical properties, $\mathrm{pH}$, and $\mathrm{EC}$ of rice hull compost, from the other compost blends. Other factors that were not measured may have also contributed to success of the rice hull compost blends. For example, rice hulls contain high levels of silicon (Gachukia and Evans, 2008), which have been shown to alleviate stress and improve plant growth (Neocleous 2015; Shi et al. 2016), and may be helpful in transplant establishment, especially under stressful field conditions.

The best results were achieved with the $30-50 \%$ rice hull compost blends. It is unclear which physiochemical factors were most important in influencing plant growth, but it seems that the physical properties of media had a greater influence on plant growth than measured nutrient concentration in media. Perhaps, even better results could be achieved with greater proportions of peat replacement or with blends using multiple composts. While rice hull compost is the preferable replacement for peat, plants grown in all compost blends produced yields equal or greater to the control, so they could all be acceptable replacements.
Acknowledgements The first author is thankful to the Higher Education Commission, Government of Pakistan, for providing funds (PIN \# 112-26885-2AV1-173) to carry out these studies.

Open Access This article is distributed under the terms of the Creative Commons Attribution 4.0 International License (http://crea tivecommons.org/licenses/by/4.0/), which permits unrestricted use, distribution, and reproduction in any medium, provided you give appropriate credit to the original author(s) and the source, provide a link to the Creative Commons license, and indicate if changes were made.

\section{References}

Beeson RC (1996) Composted yard waste as a component of container substrates. J Environ Hort 14:115-121

Bingham FT (1982) Boron. In: Page AL (ed) Methods of soil snalysis part II: chemical and microbiological properties. ASA and SSSA, Madison, pp 431-448. doi:10.2134/agronmonogr9.2.2ed

Blievernicht A, Irrgang S, Zander M, Ulrichs C (2012) The youngest peat-sustainable production of peat moss and its use as growing medium in professional horticulture. In: 14th International Peat Congress Extended abstract, pp 1-7

Bullock CH, Collier MJ, Convery F (2012) Peatlands, their economic value and priorities for their future management-The example of Ireland. Land Use Policy 29:921-928. doi:10.1016/j.land usepol.2012.01.010

Bunt AC (1988) Media and mixes for container-grown plants. Springer, Netherlands. doi:10.1007/978-94-011-7904-1

Bustamante MA, Paredes C, Moral R, Agulló E, Pérez-Murcia MD, Abad M (2008) Composts from distillery wastes as peat substitutes for transplant production. Resourc Conserv Recyc 52:792-799. doi:10.1016/j.resconrec.2007.11.005

Ceglie FG, Bustamante MA, Amara MB, Tittarelli F (2015) The challenge of peat substitution in organic transplant production: optimization of growing media formulation through mixture design and response surface analysis. PLoS One. doi:10.1371/ journal.pone. 0128600

CEN (1999) Soil improvers and growing media: determination of $\mathrm{pH}$. CEN/TC 223:9, European Committee for Standardization, Brussels. doi:10.3403/30208726

Chong C (2005) Experiences with wastes and composts in nursery substrates. HortTechnology 15(4):739-747

Cleveland WS, Devlin SJ (1988) Locally weighted regression: an approach to regression analysis by local fitting. J Am Stat Assoc 83:596-610. doi:10.1080/01621459.1988.10478639

Do T, Scherer H (2013) Compost as growing media component for salt-sensitive plants. Plant Soil Environ 59:214-220

Dole JM, Wilkins HF (1999) Floriculture principles and species. Prentice Hall, Upper Saddle River

Evans MR, Buck JS, Sambo P (2011) The pH, electrical conductivity, and primary macronutrient concentration of sphagnum peat and ground parboiled fresh rice hull substrates over time in a greenhouse environment. HortTechnology 21:103-108. doi:10. 17660/actahortic.2014.1018.57

Gachukia MM, Evans MR (2008) Root substrate pH, electrical conductivity, and macroelement concentration of sphagnum peat-based substrates amended with parboiled fresh rice hulls or perlite. HortTechnology 18:644-649

Ghehsareh AM (2013) Effect of date palm wastes and rice hull mixed with soil on growth and yield of cucumber in greenhouse culture. Int J Recycl Org Waste Agric 2(1):1-5. doi:10.1186/2251-7715-2-17

Ghehsareh AM, Hematian M, Kalbasi M (2012) Comparison of datepalm wastes and perlite as culture substrates on growing indices 
in greenhouse cucumber. Int J Recycl Org Waste Agric 1(1):1-4. doi:10.1186/2251-7715-1-5

Ghehsareh AMN, Samadi N, Borji H (2013) Comparison of datepalm wastes and perlite as growth substrates on some tomato growing indexes. Afr J Biotechnol 10:4871-4878. doi:10.1186/ 2251-7715-1-5

Grains TP, Mitchell GA (1979) Boron determination in plant tissue by the Azomethine-H method. Commu Soil Sci Plant 10:1099-1108. doi:10.1080/00103627909366965

Gupta R, Yadav A, Garg VK (2014) Influence of vermicompost application in potting media on growth and flowering of marigold crop. Int J Recycl Org Waste Agric 3(1):1-7. doi:10. 1007/s40093-014-0047-1

Haghighi M, Barzegar MR, da Silva JAT (2016) The effect of municipal solid waste compost, peat, perlite and vermicompost on tomato (Lycopersicum esculentum) growth and yield in a hydroponic system. Int J Recycl Org Waste Agric. doi:10.1007/ s40093-016-0133-7

Hartz TK, Costa FJ, Shrader WL (1996) Suitability of composted green waste for horticultural uses. HortScience 31:961-964

Inckel M, Smet PD, Tersmette T, Veldkamp T (2005) The preparation and use of compost, 7th edn. Agromisa Foundation, Netherlands

Jackson ML (1962) Soil chemical analysis. Constable \& Co., Ltd., London

Jackson BE, Wright RD, Barnes MC (2008) Pine tree substrate, nitrogen rate, particle size, and peat amendment affect poinsettia growth and substrate physical properties. HortScience 43(7):2155-2161

Jones JB, Wolf B, Mills HA (1991) Plant analysis handbook. MicroMacro Publishing Inc, Athens

Jung JY, Yang JK (2014) The suitability evaluation of lignocellulosic substrate as growing media substitute. Afr $\mathbf{J}$ Biotechnol 13:1541-1549. doi:10.5897/ajb2012.2963

Kuisma E, Palonen P, Yli-Halla M (2014) Reed canary grass straw as a substrate in soilless cultivation of strawberry. Sci HorticAmsterdam 178:217-223. doi:10.1016/j.scienta.2014.09.002

Lamont JR, Elliott GE (2016a) Anaerobically digested dairy fiber in soilless potting media for herbaceous perennials. Am J Plant Sci 7:288-295. doi:10.4236/ajps.2016.72028

Lamont JR, Elliott GE (2016b) Anaerobically digested dairy fiber in soilless potting media for poinsettias. Int $\mathrm{J}$ Recycl Org Waste Agric 5:173-177. doi:10.1007/s40093-016-0130-x

Lopes RX, Zied DC, Martos ET, de Souza RJ, Da Silva R, Dias ES (2015) Application of spent Agaricus subrufescens compost in integrated production of seedlings and plants of tomato. Int $\mathbf{J}$ Recycl Org Waste Agric 4(3):211-218. doi:10.1007/s40093015-0101-7

Mahmoud AM, Afifi M, El-Helaly M (2014) Production of organic tomato transplants by using compost as alternative substrate for peat-moss. Am Eurasian J Agric Environ Sci 14:1095-1104

Mustafa G, Ali MA, Abid M, Masood S, Ahmad N, Aamer M, Qayyum MF, Hussain S (2016) Comparison of various potting media for their influence on nutrients supply, germination, and growth of muskmelon (cucumis melo L.) transplants. Compost Sci Util 24:61-71. doi:10.1080/1065657x.2015.1064047

Neocleous D (2015) Grafting and silicon improve photosynthesis and nitrate absorption in melon (Cucumis melo L.) plants. J Agric Sci Technol 17:1815-1824

Nkongolo NV, Caron J (1999) Bark particle sizes and the modification of the physical properties of peat substrates. Can J Soil Sci 79:111-116. doi:10.4141/s96-084

Okafor FO, Okonkwo UN (2009) Effects of rice husk ash on some geotechnical properties of lateritic soil. J Pract Technol 8:67-74

Raviv M (2005) Production of high-quality composts for horticultural purposes: a mini-review. HortTechnology 15:52-57

Raviv M (2011) The future of composts as ingredients of growing media. Int Symp Grow Media Compos 891:19-32. doi:10.17660/ ActaHortic.2011.891.1

Roberston RA (1993) Peat, horticulture and environment. Biodivers Conserv 2:541-547. doi:10.1007/BF00056747

Sánchez-Monedero MA, Roig A, Cegarra J, Bernal MP, Noguera P, Abad M, Antón A (2004) Composts as media constituents for vegetable transplant production. Compost Sci Util 12:161-168. doi:10.1080/1065657x.2004.10702175

Sendi H, Mohamed M, Anwar M, Saud H (2013) Spent mushroom waste as a media replacement for peat moss in Kai-Lan (Brassica oleracea var. Alboglabra) production. Sci World J 1:1-8. doi:10.1155/2013/258562

Sharif N, Ishfaq M, Memon N, Riaz S (2014) Standardization of potting media for nursery raising transplants of jujube (Zyzyphus mauritiana Lamk.). J Agric Technol 10:1231-1239

Sharman KV, Bodman K (1993) Container media management. Queensland Department of Primary Industries, Australia

Sheskin DJ (2004) Handbook of parametric and nonparametric statistical procedures, 3rd edn. Chapman and Hall, New York

Shi Y, Zhang Y, Han W, Feng R, Hu Y, Guo J, Gong H (2016) Silicon enhances water stress tolerance by improving root hydraulic conductance in Solanum lycopersicum L. Front Plant Sci . doi:10.3389/fpls.2016.00196

Steiner C, Harttung T (2014) Biochar as a growing media additive and peat substitute. Solid Earth 5(2):995

Torkashvand AM, Alidoust M, Khomami AM (2015) The reuse of peanut organic wastes as a growth medium for ornamental plants. Int J Recycl Org Waste Agric 4(2):85-94. doi:10.1007/ s40093-015-0088-0

Yoshida S, Forno DA, Cock JH, Gomez KA (1978) Laboratory manual for physiological studies of rice. Int Rice Res Inst, Manila

Zaccone C, Miano TM, Shotyk W (2007) Qualitative comparison between raw peat and related humic acids in an ombrotrophic bog profile. Org Geochem 38(1):151-160. doi:10.1016/j.orggeo chem.2006.06.023

Zaccone C, Rein G, D'Orazio V, Hadden RM, Belcher CM, Miano TM (2014) Smouldering fire signatures in peat and their implications for palaeoenvironmental reconstructions. Geochim Cosmochim Acta 137:134-146. doi:10.1016/j.gca.2014.04.018 